\title{
Sociobiology
}

RESEARCH ARTICLE - ANTS

\section{A Quantitative Baseline of Ants and Orchid Bees in Human-Modified Amazonian Landscapes in Paragominas, Pará, Brazil}

\author{
RRC SOLAR ${ }^{1,2,3}$, JCM CHAUL'2 M MAUÉS ${ }^{4}$, JH SCHOEREDER ${ }^{2}$ \\ 1 - Instituto de Ciências Biológicas, Universidade Federal de Minas Gerais, Belo Horizonte-MG, Brazil \\ 2 - Programa de Pós-graduação em Ecologia, Universidade Federal de Viçosa-MG, Brazil \\ 3 - Lancaster University, Lancaster UK \\ 4 - Embrapa Amazônia Oriental, Belém-PR, Brazil
}

\section{Article History \\ Edited by \\ Gilberto M. M. Santos, UEFS, Brazil \\ Received 27 April 2016 \\ Initial acceptance 24 August 2016 \\ Final acceptance 18 September 2016 \\ Publication date 25 October 2016}

\section{Keywords}

Amazon Rainforest, Biodiversity baselines, Conservation, Land-use change, Monitoring.

\section{Corresponding author}

Ricardo RC Solar;

ICB/UFMG, Departamento de Biologia

Geral, Sala 13-245

Avenida Antônio Carlos, no 6627

CEP 31270-901, Belo Horizonte-MG, Brasil

E-Mail: rrsolar@gmail.com

\begin{abstract}
The lack of effective biodiversity baselines is a major impairment to implement conservation plans. Hence, constructing and updating species lists provides vital information about species distribution records. The Sustainable Amazon Network (in Portuguese Rede Amazônia Sustentável; RAS) is an interdisciplinary research initiative that aims to evaluate land-cover changes effects in eastern Brazilian Amazonia. Within the scope of this project, we sampled ants and orchid bees and herein present a list of species collected in Paragominas, PA, Brazil; the most complete lists of species published to date of these groups for the eastern Amazon. We sampled these insects across several land-cover types, from undisturbed forested habitats, through varyingly disturbed forested habitats and secondary forests to production areas (silviculture, pastures and arable fields). In total we recorded 285 species of ants and 36 species of orchid bees. Species richness was higher in primary forests for both groups, followed by production areas. Orchid bees reached their highest richness in secondary forests. For orchid bees, production areas were dominated by a few hyper-dominant species, such as Eulaema nigrita. For future assessments if the aim is to make a complete inventory, we recommend the use of additional sampling methods. Finally, we expect this study can be used as a baseline for understanding the effectiveness of ongoing changes in forest conservation and land management practices and in determining conservation status for several taxa described here.
\end{abstract}

\section{Introduction}

Tropical forest ecosystems are the richest ecosystems on Earth (Pimm and Raven 2000), harboring up to two thirds of the planet biodiversity (Gardner et al., 2009). Yet, the region has been suffering intense human-impacts and is the among the most actives frontiers of land-cover changes in the world (Malhi et al., 2008). In Brazil, government efforts were yielding positive results, and deforestation rates have decreased from 2004 to 2014, although these rates have increased recently (PRODES-INPE 2015). Given this loss and modification of Amazonian forest habitats, it is critical to understand the ramifications for regional biodiversity in order to foster conservation plans and actions in the region. Nevertheless, due to poor infrastructure and the vast size of the region, our knowledge about Amazonian biodiversity, particularly non-vertebrates is limited and most species lists underestimate total biodiversity (Barlow et al., 2011). Given that habitat loss is the most serious threat facing tropical biodiversity (Laurance et al., 2014), regional inventories represent an important step for the conservation of insect communities. Understanding patterns of species occurrence in 
space and time, as well as across human-modified landscapes is a valuable tool for studying population ecology and biodiversity responses to human impacts in order to judge which human activities are most affecting biodiversity (Lach et al., 2010).

The Sustainable Amazon Network (in Portuguese, Rede Amazônia Sustentável, RAS, Gardner et al., 2013) assessed the biodiversity, ecosystem services and social aspects of human-modified forest landscapes in two frontier regions (Paragominas and Santarém-Belterra) of the eastern Brazilian Amazon, in the state of Pará. These regions have suffered from intense deforestation since the 1970's (Lindenmayer et al., 2004), although several governmental and social initiatives have been contributing to minimize and revert this process (Viana et al., 2016). Within the municipality of Paragominas, RAS fieldwork sampled trees and lianas (Berenguer et al., 2014), birds (Lees et al., 2012) and here we present data on a comprehensive survey of two terrestrial invertebrate groups: ants (Hymenoptera: Formicidae) and orchid bees (Hymenoptera: Apidae: Euglossina) selected for their ecological importance.

Ants (Hymenoptera: Formicidae) are a ubiquitous group, being numerically and ecologically dominant in tropical forests (Hölldobler \& Wilson 2009; Lach et al., 2010). They play roles as seed dispersers (Christianini et al., 2007), in moving nutrients across soil horizons (SousaSouto et al., 2007) and in regulating populations of prey species (Folgarait, 1998). Ants are also easy to sample, have a relatively well established taxonomy and are numerically dominant nearly everywhere in the Neotropics throughout the year (Underwood \& Fisher, 2006).

Orchid bees encompasses around 250 species endemic to the Neotropics (Nemesio \& Rasmussen, 2011). One of the striking characteristics of this group is pollination of tightly associated plant species (Janzen, 1971). Given their sensitivity to environmental change (Nemesio \& Vasconcelos, 2013) and ease with which they can be sampled makes them a costeffective ecological disturbance indicator group (Gardner et al., 2008).

Here we present an annotated checklist of ants and orchid bees collected in Paragominas, PA, Brazil; the most complete list species list produced to date for the western Amazon that, together with other efforts already conducted in the region (e.g. Kempf, 1970; Kalif et al., 2001; Santos et al., 2008) establishes a crucial biodiversity baseline for ongoing environmental monitoring.

\section{Methods}

Study site

We sampled the insects in Paragominas, a 2 million ha Amazonian municipality in Pará state, northeastern Brazil (Fig 1). The region was originally almost entirely covered with evergreen forests and regional climate is Am according to the Köppen classification (Alvares et al., 2013) with an average annual rainfall of $1800 \mathrm{~mm}$ (Andrade, 2011) and mean annual temperatures of $26.3^{\circ} \mathrm{C}$ (Pinto et al., 2009). We conducted all fieldwork between January-June 2011, during the rainy season.

Sampling was undertaken in $18 \mathrm{ca} .5 .000$ ha. catchments covering the entire municipality ( 2 million hectares), distributed along a gradient of deforestation from undisturbed primary forest through varyingly disturbed primary forests, secondary forests, pastures and mechanized agriculture, where we established from 8-12 transects $(300 \mathrm{~m})$ in each catchment, in a density of 1 transect/400ha (Fig 1). In total, we sampled 192 transects across the major land-use classes present in the region including undisturbed primary forests, varyingly disturbed (from logging and fire) primary and secondary forests and production areas (silviculture - Eucalyptus and Schyzolobium amazonicum, cattle pastures and arable fields).

\section{Insect sampling}

Within each transect we sampled both insect groups concurrently. Ants were sampled with epigaeic pitfall traps, composed of plastic containers $(8 \mathrm{~cm}$ diameter) half filled with a solution of water, salt (5\%) and soap (5\%) and baited with sardines and honey, both inaccessible to the ants. In each transect we installed six pitfall traps separated $50 \mathrm{~m}$ from one another.

To sample orchid bees, we used four plastic bottles per transect, with one scent bait each $(2 \mathrm{~L}, 10 \mathrm{~cm}$ diameter, $35 \mathrm{~cm}$ height), tied to a tree trunk, $1.5 \mathrm{~m}$ above the ground. Male orchid bees were attracted to four types of scent baits (eugenol, methyl salicylate, vanilla and eucalyptol), separated by $50 \mathrm{~m}$ from each other. In both cases traps remained in the field for $48 \mathrm{~h}$ prior to removal, see Fig 1 for a graphical representation of our sampling design.

We processed and identified the ants to the most precise taxonomic level possible using genera taxonomic keys (Fernández, 2003, Baccaro et al., 2015), and the most upto-date taxonomic revisions of each taxa, directly comparing with the available type images on AntWeb (Available from http://www.antweb.org. Accessed in April/2016), and checked against the reference collection of the Community Ecology Lab, affiliated with the Museu Regional de Entomologia da Universidade Federal de Viçosa (UFVB). We checked all the species in Ant Cat (Bolton; http://antcat. org, accessed in April/2016) to confirm the validity of the nomenclature we used.

We processed and identified orchid bees at EMBRAPA - Amazônia Oriental, adapting available taxonomic keys (Nemesio, 2009) and using the reference collection of EMBRAPA - Amazônia Oriental. A taxonomist, Dr André Nemésio, checked species identifications. We deposited voucher specimens of ants in the reference collection of the Community Ecology Lab, Universidade Federal de Viçosa. Orchid bees are deposited on the reference collection in EMBRAPA - Amazônia Oriental. 


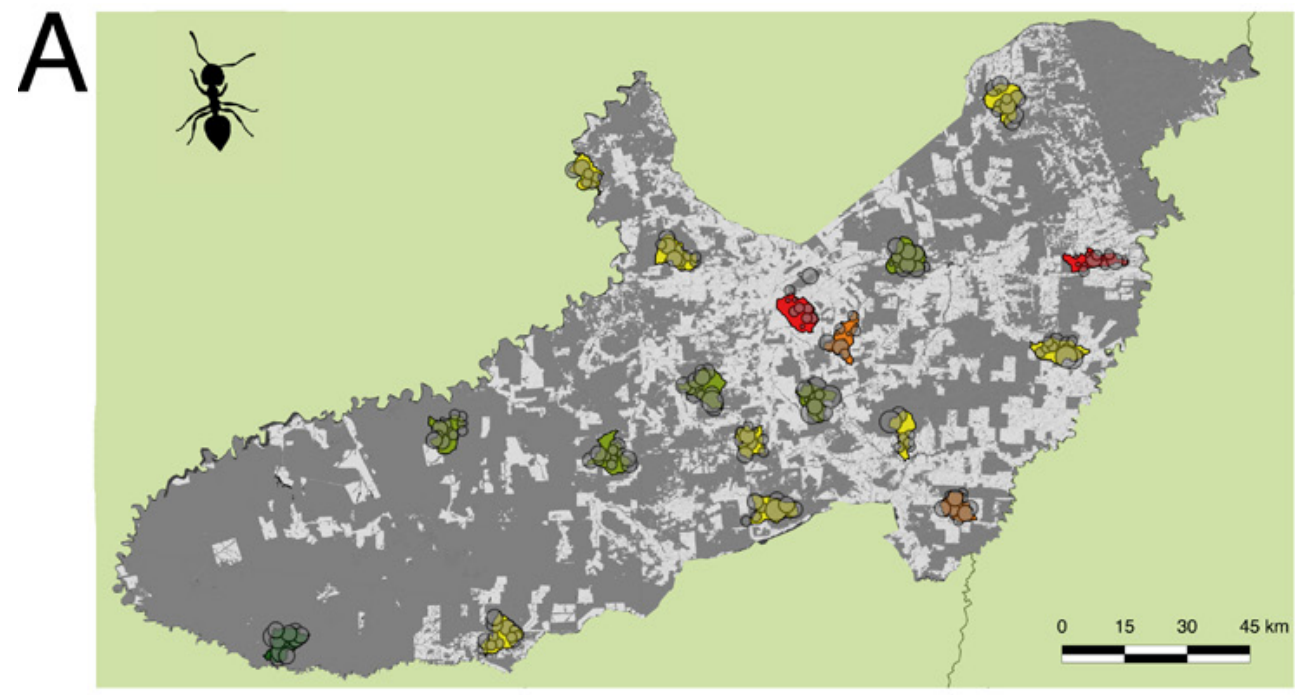

Legend

\begin{tabular}{|c|c|c|}
\hline Ant species richness & Forest cover (Catchment) & Land cover class \\
\hline . $1 \cdot 12$ & $6 \cdot 15$ & Forest \\
\hline - $12 \cdot 24$ & $15 \cdot 22$ & Non-forest \\
\hline $24 \cdot 35$ & $\square 22 \cdot 57$ & \\
\hline 35.46 & $57 \cdot 75$ & \\
\hline
\end{tabular}

B

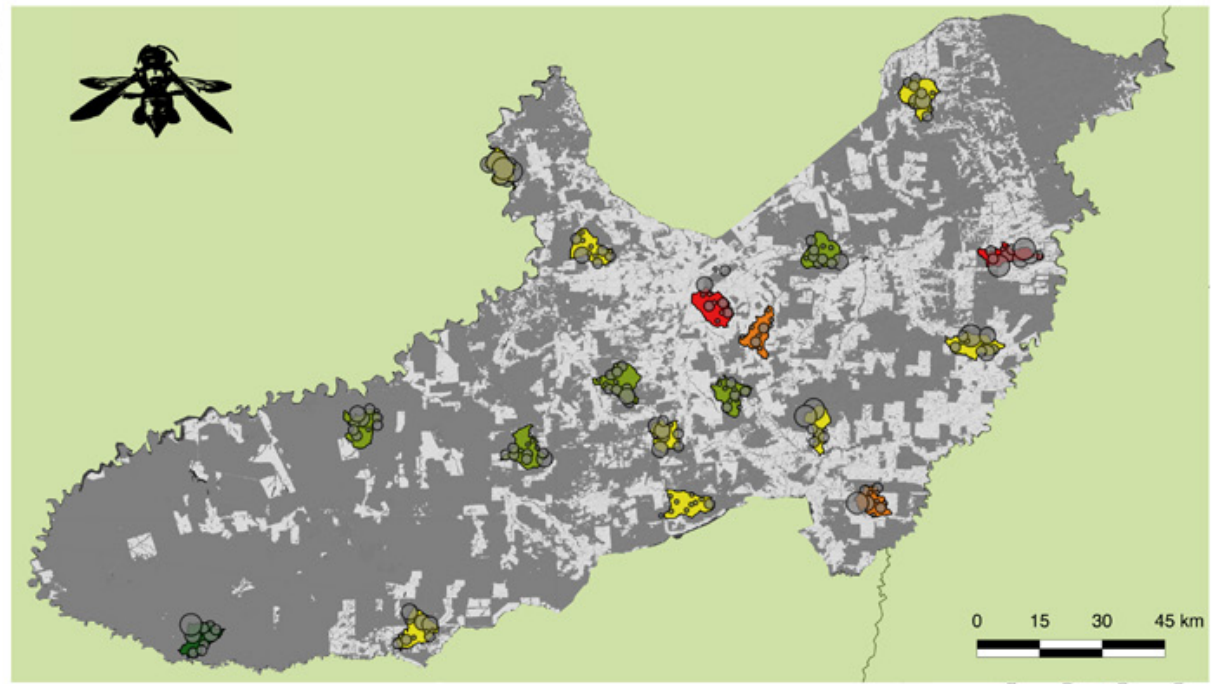

Legend

Orchid bee species richness Forest cover (Catchment) Land cover class

- $1-12$

อ $12-24$

$24-35$

$35 \cdot 46$

$\begin{array}{ll}6-15 & \text { Forest } \\ 15-22 & \text { Non-forest } \\ 22-57 & \\ \square 7-75 & \\ 75-100 & \end{array}$

\section{Statistical analyses}

To assess our sampling sufficiency, we built sitebased species accumulation curves (Colwell et al., 2004) and estimated the total number of species sampled in each taxon using the first order Jackknife richness estimator. All analyses were performed using the R v.3.1.2 (R Core Team 2015), using the package vegan (Oksanen et al., 2015).

\section{Results}

For both groups, species richness was higher in forested areas (average \pm standard deviation; Ants $25.2 \pm 7.3$;
Fig 1. Map of the sampling region within the Brazilian contexts. Circles represent each sampled transect and circle sizes represent relative species richness for each taxa. In colours are represented micro-catchments, where samplings were located and greener colours represent higher primary forest cover, while redder colours represent lower primary forest cover.

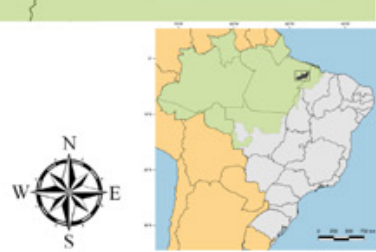

Bees $6.45 \pm 3.8$ ) and lower in production areas (average \pm standard deviation; Ants $16.9 \pm 6.0$; Bees $3.8 \pm 2.5$ ). Worth of highlighting, the richest assemblage of orchid bees was found in secondary forests. In Table 1, we present how species richness of both groups was distributed in transects across the studied land-use classes.

Ants

We sampled a total of 285 species of ants, in 60 genera, belonging to nine subfamilies. We assigned a name to all genera and among them, 132 were identified to specieslevel or very close to a given taxa, and 11 were assigned to 
species groups or complexes where exact species identification was impossible. The remaining 142 are identified and were assigned a morphospecies code that applies only to this study. A list of the species and morphospecies is given in Table 2. At least two new species of the genera Xenomyrmex (Xenomyrmex PGM-01) and Hylomyrma (Hylomyrma PGM01) were sampled (L. do Prado and M. Ulysséa, personal communications, respectively) and these specimens are deposited at the Museu de Zoologia da Universidade de São Paulo. By comparing with the type photos (AntWeb Available from http://www.antweb.org. Accessed in March 2015) and/or original descriptions, we considered some species in the list of ants to be slightly different from the original species (e.g. Strumigenys aff. perparva; Pachycondyla aff. purpurascens) and are therefore treated as morphospecies very close to that particular species. It remains to be investigated whether each of them represent still undescribed sister species or a case of intraspecific variation. Others were tentatively assigned to a given taxa but precise identification was not possible (e.g. Sericomyrmex cf. parvulus). The regional species accumulation curve is not asymptotic but does flatten towards the end (Fig $2 \mathrm{a}$ ), and the $1^{\text {st }}$ order Jackknife estimator suggests that we sampled $77.5 \%$ of the total species richness.
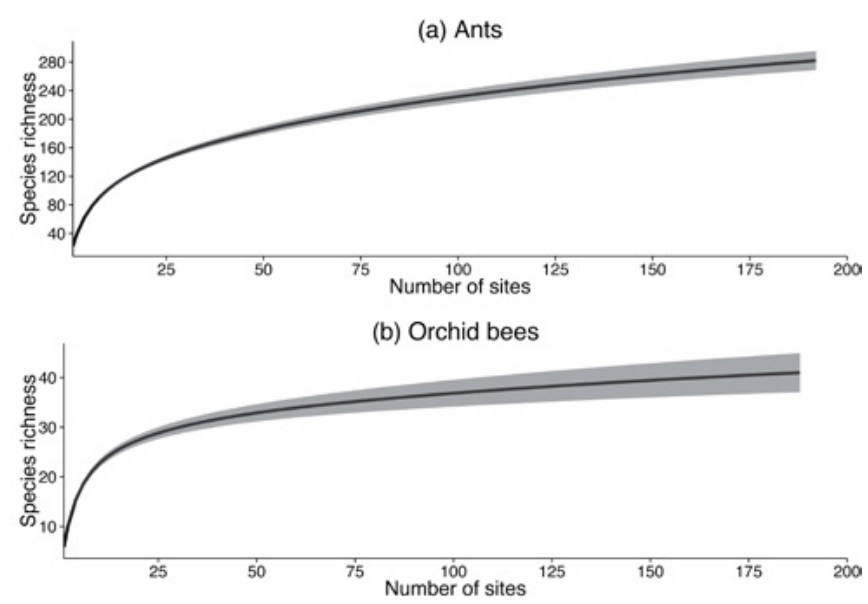

Fig 2. Species accumulation curves for both studied taxonomic groups. Each curve was drawn after 10.000 randomisations of original data and the shaded area represents the standard deviation. In the $\mathrm{x}$-axis we have number of sampled transects, in the y-axis, accumulated species richness.

\section{Orchid bees}

We sampled 3,769 orchid bees of 36 species, belonging to four of the five known genera in the group. Out of the total, 34 species could be identified to species level. Only one species of Eufriesea and one Eulaema were assigned to morphospecies. The complete list of species is available in Table 3. Species accumulation curves were near asymptotic (Fig 2b), and we sampled $87 \%$ of the total species richness estimated by $1^{\text {st }}$ the order Jackknife estimator.
Table 1. Average species richness \pm confidence intervals for species richness of each taxon per transect in each land-use type.

\begin{tabular}{lcc}
\hline & \multicolumn{2}{c}{ Taxon } \\
\cline { 2 - 3 } Land-use class & Ants & Orchid-bees \\
\hline Undisturbed forest & $28.56( \pm 3.4)$ & $4.85( \pm 2.6)$ \\
Logged forest & $25.72( \pm 2.1)$ & $6.46( \pm 0.9)$ \\
Logged and burned forest & $27.25( \pm 2.1)$ & $6.46( \pm 1.1)$ \\
Secondary forest & $23.09( \pm 2.9)$ & $8.39( \pm 1.6)$ \\
Reforestation $($ Eucalyptus $)$ & $16.50( \pm 4.1)$ & $4.42( \pm 2.0)$ \\
Pasture & $17.70( \pm 1.6)$ & $4.22( \pm 0.7)$ \\
Agriculture & $12.93( \pm 2.9)$ & $2.53( \pm 0.9)$ \\
\hline
\end{tabular}

\section{Discussion}

Our study is the most comprehensive sampling to date of ants and orchid bees for any area of the eastern Amazon and we hope it both fosters future biodiversity studies in the region, and can be used as an evidence-baseline for future Red Listing classification exercises for invertebrates. We consider our sampling effort sufficient for both taxa at the regional scale, with at least $77 \%$ of the estimated diversity sampled for all taxa. For ants, the only previous study we are aware of in Paragominas yielded only 74 species belonging to 30 genera (Kalif et al., 2001). Even so, by using a different sampling method (Winkler extractors), this study sampled species not represented in our study, demonstrating the importance of implementing complementary methods of sampling to survey this region. Exploring seldom-studied habitats such as the forest canopy (Basset et al., 2012) or underground soil layers (Wilkie et al., 2007; Schmidt \& Solar, 2010; Schmidt et al., 2014) also offers significant potential to increase the number of species described for the region.

Orchid-bees are poorly known in the Amazonian region, our total of 36 species is of a similar magnitude as other studies in current and former terra-firme forest habitats in the region (Oliveira \& Campos, 1996; Rasmussen, 2009; Storck-Tonon et al., 2009; Abrahamczyk et al., 2011). We sampled in a very diverse range of habitats and in a large area, however additional species are likely to be encountered using a greater range of bait types (Nemesio \& Vasconcelos, 2013). For both taxa, we acknowledge that by sampling only during the rainy season, we might have missed some species that prefer dry climates. We believe this was not the case for ants, as they are colonial organisms and are know to be far more active during the rainy season (Hölldobler \& Wilson, 2009), improving capture by pitfall traps. Orchid bees do have marked seasonality (Abrahamczyk et al., 2012; Abrahamczyk et al., 2014), however the highest species richness for this group is found in the rainy season (Abrahamczyk et al., 2011). In order to cover a larger area as possible, while capturing the maximum diversity, we opted to sample during the rainy season.

Unsurprisingly we found forests to be more species rich than non-forest habitats, as was the case for other taxonomic 
groups in the same study region (e.g. Moura et al., 2013). However, it is worth highlighting here that in a detailed analysis of ant responses to land-use changes and forest disturbance, we observed more subtle patterns of diversity within and between the major land-use types (Solar et al., 2016). Studies on ants and other groups have been showing that the recovery of species diversity in disturbed forests is not guaranteed, even when considering samples conducted relatively mature secondary forests on average (Wilkie et al., 2009; Barlow et al., 2016; Solar et al., 2016).

By contrast the orchid bees exhibited similar levels of richness in all forest types, with highest richness in secondary forests. This is an expected result, considering orchid bees have high vagility, being able to fly several kilometers a day (Janzen, 1971), which in turn could cause high rates of spillover. On the other hand, they may rapidly colonize new habitats, and may persist in small forest patches (Nemesio \& Silveira, 2007, 2010). Nevertheless, orchid bees are seriously affected by deforestation and forest fragmentation (Nemesio \& Silveira, 2010) and forest-dependent species are seriously threatened; see Nemesio (2013) for case study in the Atlantic forest.

Open areas are often the least hospitable environments (Gascon et al., 1999), and are commonly dominated by generalist species. This is the case of the orchid bee Eulaema nigrita Lepeletier de Saint Fargeau, 1841. This species is an example of a non-forest species, which can be rarely recorded in forest fragments but is highly abundant in open areas. Compared with Eu. nigrita, all other species in pasture transects had a relative occurrence frequency of less than $1 \%$.

\section{Conservation implications}

Enhanced documentation of local diversity patterns of insects and other organisms are invaluable in helping to assess conservation priorities and assess management effectiveness. Indeed, it would be highly desirable to develop conservation strategies or conclusions taking into account a more comprehensive understanding of diversity and distribution of the major groups of organisms inhabiting a given locality. We hope this assessment provides the baseline for new community and population studies on these groups of insects in the region. Paragominas is the flagship municipality in the state of Para for the Green Municipalities Program (in Portuguese, Programa Municipios Verdes - http://municipiosverdes.com.br/), an initiative aiming to stop deforestation and promote secondary forest recovery and sustainable land-use practices in the region (Viana et al. 2016). We suggest therefore this study and the patterns of species distributions can be used as baselines for future studies of forest changes in that region to assess the conservation success of the program.

\section{Acknowledgements}

We are indebted to the invaluable dedication of our field assistants and support received from the farmers and community of Paragominas. We are grateful to Dr. Rodrigo Feitosa, Dr. André Nemésio; Thalyane A. Moura; Lívia P. Prado and Mônica A. Ulysséa for their invaluable help in species identification. We are grateful to Alexander C. Lees, Ricardo Campos, Tathiana Sobrinho and Frederico Neves, for their suggestions in the first draft of this manuscript. Alexander C. Lees revised English grammar and spelling. We received financial support from Instituto Nacional de Ciência e Tecnologia - Biodiversidade e Uso da Terra na Amazônia (CNPq 574008/2008-0), Empresa Brasileira de Pesquisa Agropecuária - Embrapa (SEG:02.08.06.005.00), the UK government Darwin Initiative (17-023), The Nature Conservancy, and Natural Environment Research Council (NERC) (NE/F01614X/1 and NE/G000816/1). RRCS is funded by CAPES/PNPD. JHS is funded by CNPq. This is the contribution number 51 of the Sustainable Amazon Network (http://www.redeamazoniasustentavel.org).

Table 2. List of ant species collected in this study. Values represent number of records per pitfall traps of each species in each land-use type: PFU - primary forest undisturbed, PFL - primary forest logged, PFLB - primary forest logged and burnt, SEF - secondary forest, REF reforestation with commercial species, PAS - pasture, AGR - agricultural areas.

\begin{tabular}{|c|c|c|c|c|c|c|c|c|}
\hline \multirow[b]{2}{*}{ Species } & \multirow[b]{2}{*}{ Author } & \multicolumn{7}{|c|}{ Land-use type } \\
\hline & & PFU & PFL & PFLB & SEF & REF & PAS & AGR \\
\hline \multicolumn{9}{|l|}{ AMBLYOPONINAE } \\
\hline \multicolumn{9}{|l|}{ DOLICHODERINAE } \\
\hline Azteca alfari & Emery, 1893 & 1 & 1 & & & & & \\
\hline Azteca ovaticeps & Forel, 1904 & & 2 & & & & & \\
\hline Azteca PGM-03 & & & & 1 & & & & \\
\hline Azteca aurita & Emery, 1893 & & 1 & & & & & \\
\hline Dolichoderus bispinosus & (Olivier, 1792) & & & 2 & 1 & & 2 & \\
\hline Dolichoderus decollatus & Smith, 1858 & & 2 & & & & & \\
\hline
\end{tabular}


Table 2. List of ant species collected in this study. Values represent number of records per pitfall traps of each species in each land-use type: PFU - primary forest undisturbed, PFL - primary forest logged, PFLB - primary forest logged and burnt, SEF - secondary forest, REF reforestation with commercial species, PAS - pasture, AGR - agricultural areas. (Continuation)

\begin{tabular}{|c|c|c|c|c|c|c|c|c|}
\hline \multirow[b]{2}{*}{ Species } & \multirow[b]{2}{*}{ Author } & \multicolumn{7}{|c|}{ Land-use type } \\
\hline & & PFU & PFL & PFLB & SEF & REF & PAS & AGR \\
\hline \multicolumn{9}{|l|}{ DOLICHODERINAE } \\
\hline Dolichoderus imitator & Emery, 1894 & 1 & & & & & & \\
\hline Dolichoderus lutosus & (Smith, 1858) & & 1 & & & & & \\
\hline Dolichoderus varians & Mann, 1916 & & & 2 & & & & \\
\hline Dorymyrmex cf. goeldii & Forel, 1904 & & & & & & 6 & 3 \\
\hline Dorymyrmex PGM-01 & & 1 & 1 & & 2 & 15 & 9 & 7 \\
\hline Dorymyrmex PGM-02 & & & & & & 1 & 1 & 1 \\
\hline Dorymyrmex spurius & Santschi, 1929 & & 2 & 1 & 3 & 9 & 15 & 12 \\
\hline Forelius PGM-01 & & & & & & & 2 & \\
\hline Gracilidris pombero & Wild \& Cuezzo, 2006 & & & 1 & 1 & 6 & 41 & 3 \\
\hline Linepithema neotropicum & Wild, 2007 & & 2 & 12 & & 1 & & \\
\hline Tapinoma melanocephalum & (Fabricius, 1793) & 1 & 4 & 2 & 2 & 1 & 1 & \\
\hline Tapinoma PGM-01 & & 1 & & & & & 1 & \\
\hline
\end{tabular}

\section{DORYLYNAE}

Acanthostichus laticornis

Cerapachys splendens

Forel, 1908

1

Borgmeier, 1957

1

Eciton burchellii

(Westwood, 1842)

Eciton mexicanum

Roger, 1863

Eciton rapax

Smith, 1855

Labidus coecus

(Latreille, 1802)

(Forel, 1912)

(Smith, 1858)

(Emery, 1890)

Borgmeier, 1953

1

1

1

2

(Westwood, 1842)

Nomamyrmex esenbecki

ECTATOMMINAE

Ectatomma brunneum

Ectatomma edentatum

Smith, 1858

Roger, 1863

Ectatomma lugens

Ectatomma tuberculatum

Emery, 1894

(Olivier, 1792)

Gnamptogenys acuminata

(Emery, 1896)

Gnamptogenys haenschi

(Emery, 1902)

Gnamptogenys horni

(Santschi, 1929)

Gnamptogenys aff. mecotyle

Brown, 1958

Gnamptogenys moelleri

(Forel, 1912)

Gnamptogenys striatula

Mayr, 1884

1

7

4

32

32

3

154

19

88

$$
8
$$

Gnamptogenys gr. striatula PGM-02

Gnamptogenys sulcata

6

11

2

1

1

15

11

1

1

Gnamptogenys tortuolosa 
Table 2. List of ant species collected in this study. Values represent number of records per pitfall traps of each species in each land-use type: PFU - primary forest undisturbed, PFL - primary forest logged, PFLB - primary forest logged and burnt, SEF - secondary forest, REF reforestation with commercial species, PAS - pasture, AGR - agricultural areas. (Continuation)

\begin{tabular}{|c|c|c|c|c|c|c|c|c|}
\hline \multirow[b]{2}{*}{ Species } & \multirow[b]{2}{*}{ Author } & \multicolumn{7}{|c|}{ Land-use type } \\
\hline & & PFU & PFL & PFLB & SEF & REF & PAS & $\overline{A G R}$ \\
\hline \multicolumn{9}{|l|}{ FORMICINAE } \\
\hline Acropyga goeldii & Forel, 1893 & & & & & 1 & & \\
\hline Brachymyrmex PGM-01 & & & & & 1 & 1 & 3 & \\
\hline Brachymyrmex PGM-02 & & & & 3 & 1 & 11 & 42 & 25 \\
\hline Brachymyrmex PGM-03 & & 1 & & & & & & \\
\hline Brachymyrmex PGM-04 & & & 1 & 9 & 7 & & 1 & \\
\hline Brachymyrmex PGM-05 & & & & 1 & 1 & & & \\
\hline Brachymyrmex PGM-06 & & & & 1 & & & & \\
\hline Brachymyrmex PGM-07 & & & 1 & & & & & \\
\hline Camponotus ager & (Smith, 1858) & & 1 & 1 & & & & \\
\hline Camponotus atriceps & (Smith, 1858) & 5 & 36 & 39 & 21 & & & \\
\hline Camponotus aff. balzani & (Emery, 1894) & & 1 & 2 & 1 & & & \\
\hline Camponotus blandus & (Smith, 1858) & & & 1 & 8 & 7 & 52 & 1 \\
\hline Camponotus crassus & Mayr, 1862 & & & 1 & & & 2 & \\
\hline Camponotus femoratus & (Fabricius, 1804) & & 1 & & 1 & & & \\
\hline Camponotus leydigi & Forel, 1866 & & & 1 & & & 3 & 1 \\
\hline Camponotus novogranadensis & Mayr, 1870 & 2 & 1 & 4 & 7 & 0 & & \\
\hline Camponotus renggeri & Emery, 1894 & & 1 & 3 & 9 & 2 & 21 & 2 \\
\hline Camponotus senex & (Smith, 1858) & & 1 & 5 & 1 & 2 & 58 & 4 \\
\hline Camponotus sexguttatus & (Fabricius, 1793) & & & 1 & & & 5 & \\
\hline Camponotus PGM-03 & & & 1 & 24 & 7 & & & \\
\hline Camponotus PGM-04 & & & 14 & 17 & 11 & & 1 & \\
\hline Camponotus PGM-05 & & & & 2 & 1 & & & \\
\hline Camponotus PGM-08 & & & 2 & 12 & 13 & 12 & 4 & 8 \\
\hline Camponotus PGM-12 & & & 1 & & & & & \\
\hline Camponotus PGM-14 & & & 1 & 1 & & & & \\
\hline Camponotus PGM-15 & & & & & 1 & & & \\
\hline Gigantiops destructor & (Fabricius, 1804) & & 5 & 11 & 1 & & & \\
\hline Nylanderia PGM-01 & & & 1 & & & & & \\
\hline Nylanderia PGM-02 & & & 1 & 22 & 24 & 12 & 4 & 5 \\
\hline Nylanderia PGM-03 & & 7 & 12 & 7 & 1 & & & \\
\hline Nylanderia PGM-04 & & & 2 & 1 & 6 & 3 & 55 & 3 \\
\hline Nylanderia PGM-05 & & 13 & 63 & 69 & 22 & 1 & 4 & 2 \\
\hline Nylanderia PGM-06 & & & & & & & 3 & \\
\hline Nylanderia PGM-07 & & 5 & 5 & 6 & 1 & & & \\
\hline Nylanderia PGM-08 & & & & 3 & 2 & 2 & 3 & 2 \\
\hline Nylanderia PGM-09 & & & & 1 & & & & \\
\hline Nylanderia PGM-10 & & & 1 & 1 & & & & \\
\hline Nylanderia PGM-11 & & 1 & 1 & & & & & \\
\hline Paratrechina longicornis & (Latreille, 1802) & & 2 & & & 3 & & \\
\hline
\end{tabular}


Table 2. List of ant species collected in this study. Values represent number of records per pitfall traps of each species in each land-use type: PFU - primary forest undisturbed, PFL - primary forest logged, PFLB - primary forest logged and burnt, SEF - secondary forest, REF reforestation with commercial species, PAS - pasture, AGR - agricultural areas. (Continuation)

\begin{tabular}{|c|c|c|c|c|c|c|c|c|}
\hline \multirow[b]{2}{*}{ Species } & \multirow[b]{2}{*}{ Author } & \multicolumn{7}{|c|}{ Land-use type } \\
\hline & & PFU & PFL & PFLB & SEF & REF & PAS & AGR \\
\hline \multicolumn{9}{|l|}{ MYRMICINAE } \\
\hline Acromyrmex coronatus & (Fabricius, 1804) & & 1 & & & & & \\
\hline Acromyrmex laticeps & (Emery, 1905) & & & 1 & & & & \\
\hline Apterostigma carinatum & Latke, 1997 & 2 & 6 & 5 & 2 & & 1 & \\
\hline Apterostigma PGM-02 & & & & 1 & & & & \\
\hline Apterostigma PGM-03 & & & 1 & 1 & & & & \\
\hline Atta cephalotes & (Linnaeus, 1758) & & & 7 & & & 4 & \\
\hline Atta sexdens & (Linnaeus, 1758) & & 2 & 1 & 4 & & 5 & 7 \\
\hline Cardiocondyla emeryi & Forel, 1881 & & & 1 & & 8 & 1 & \\
\hline Cardiocondyla minutior & Forel, 1899 & & & 1 & & 1 & 3 & \\
\hline Carebara brevipilosa & Fernández, 2004 & 1 & 4 & 2 & 1 & & & \\
\hline Carebara inca & Fernández, 2004 & & 1 & & & & & \\
\hline Carebara urichi & (Wheeler, 1922) & 3 & 5 & 8 & 1 & 1 & & 1 \\
\hline Carebara escherichi complex PGM-03 & & 2 & 2 & 4 & 4 & & & \\
\hline Carebara lignata complex PGM-01 & & & 2 & 1 & 3 & & & \\
\hline Cephalotes atratus & (Linnaeus, 1758) & & 2 & 1 & & & & \\
\hline Cephalotes cordatus & (Smith, 1853) & & & & 1 & & & \\
\hline Cephalotes maculatus & (Smith, 1876) & & 1 & & & & & \\
\hline Cephalotes oculatus & (Spinola, 1851) & & & 3 & & & & \\
\hline Cephalotes pusillus & (Klug, 1824) & & & 1 & & & 3 & \\
\hline Crematogaster brasiliensis & Mayr, 1878 & 1 & 28 & 43 & 4 & & 2 & \\
\hline Crematogaster curvispinosa & Mayr, 1862 & & & 1 & & & & \\
\hline Crematogaster erecta & Mayr, 1866 & & 2 & 2 & 6 & & & 1 \\
\hline Crematogaster flavosensitiva & Longino, 2003 & & & 1 & 6 & 1 & & \\
\hline Crematogaster levior & Longino, 2003 & & 4 & & & & & \\
\hline Crematogaster limata & Smith, 1858 & 1 & 5 & 15 & 7 & 1 & & \\
\hline Crematogaster aff. victima & Smith, 1858 & & & & & & 1 & \\
\hline Crematogaster sotobosque & Longino, 2003 & 2 & & 2 & 2 & & & \\
\hline Crematogaster tenuicula & Forel, 1904 & 32 & 55 & 13 & 7 & & 1 & 1 \\
\hline Crematogaster PGM-01 & & & & 1 & & & & \\
\hline Crematogaster PGM-02 & & 1 & & & & & & \\
\hline Crematogaster PGM-03 & & & 3 & 5 & 6 & 17 & 98 & 25 \\
\hline Crematogaster PGM-04 & & & 1 & & & & & \\
\hline Crematogaster PGM-05 & & & 1 & 1 & 5 & & 3 & 11 \\
\hline Crematogaster PGM-06 & & & & & & 2 & 12 & \\
\hline Cyphomyrmex PGM-01 & & 1 & 1 & 9 & 3 & 2 & 17 & 3 \\
\hline Cyphomyrmex gr. rimosus PGM-02 & & & & 2 & 1 & & & 1 \\
\hline Cyphomyrmex gr. rimosus PGM-03 & & 1 & 2 & & 1 & & & \\
\hline Cyphomyrmex laevigatus & Weber, 1938 & & & 1 & & 1 & 1 & \\
\hline Cyphomyrmex rimosus & (Spinola, 1851) & 1 & & 1 & 1 & & & \\
\hline Hylomyrma PGM-01* & & & 1 & & & & & \\
\hline
\end{tabular}


Table 2. List of ant species collected in this study. Values represent number of records per pitfall traps of each species in each land-use type: PFU - primary forest undisturbed, PFL - primary forest logged, PFLB - primary forest logged and burnt, SEF - secondary forest, REF reforestation with commercial species, PAS - pasture, AGR - agricultural areas. (Continuation)

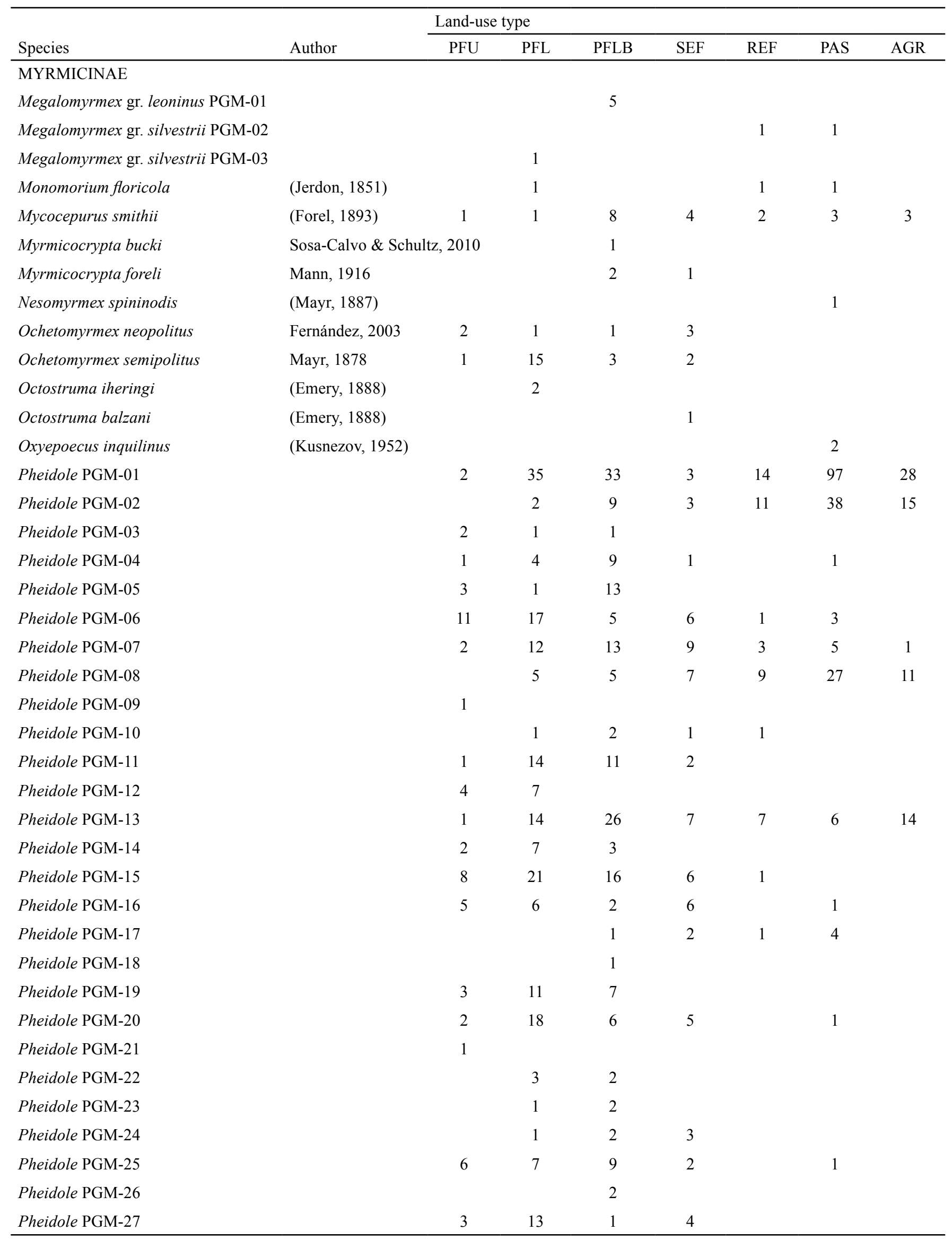


Table 2. List of ant species collected in this study. Values represent number of records per pitfall traps of each species in each land-use type: PFU - primary forest undisturbed, PFL - primary forest logged, PFLB - primary forest logged and burnt, SEF - secondary forest, REF reforestation with commercial species, PAS - pasture, AGR - agricultural areas. (Continuation)

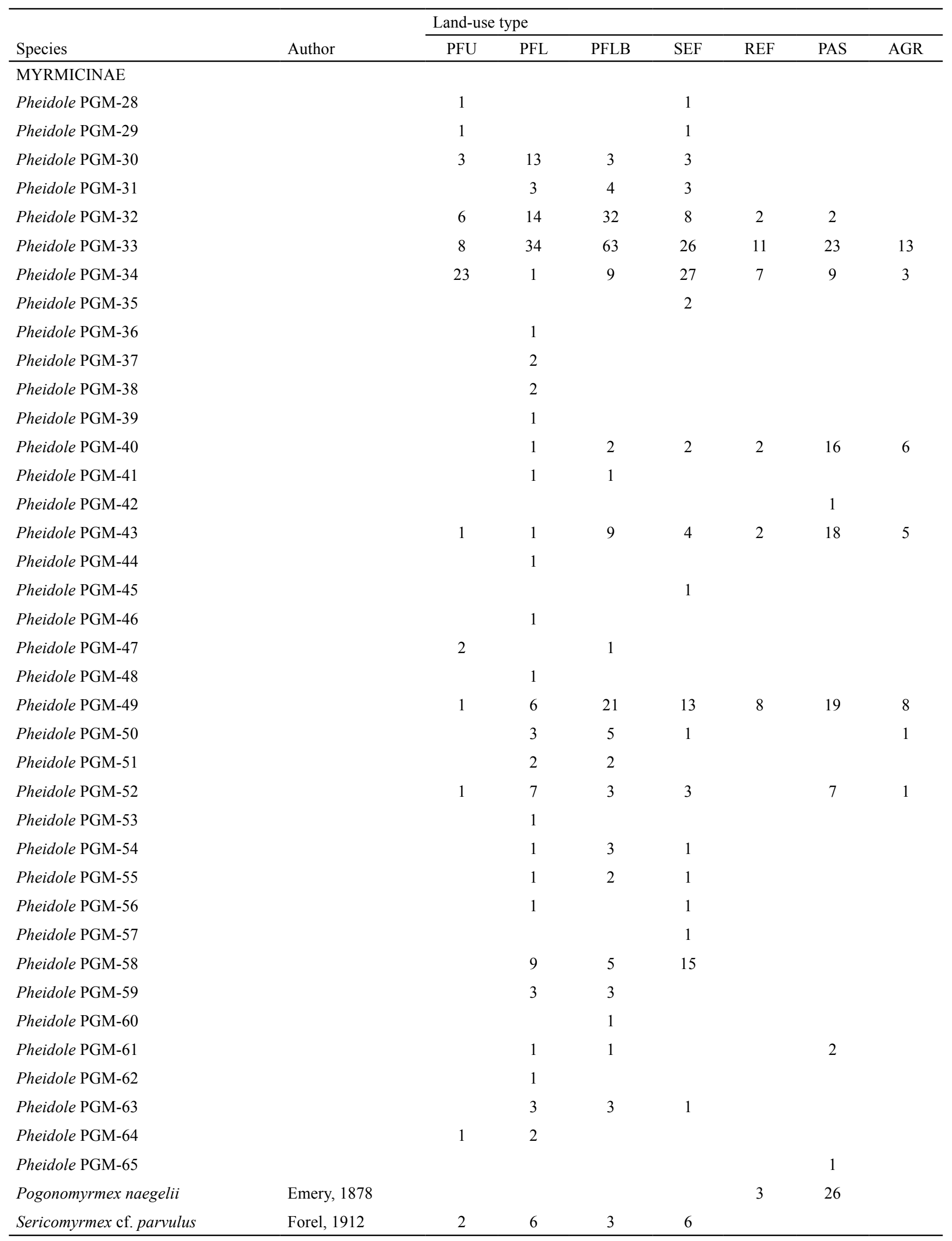


Table 2. List of ant species collected in this study. Values represent number of records per pitfall traps of each species in each land-use type: PFU - primary forest undisturbed, PFL - primary forest logged, PFLB - primary forest logged and burnt, SEF - secondary forest, REF reforestation with commercial species, PAS - pasture, AGR - agricultural areas. (Continuation)

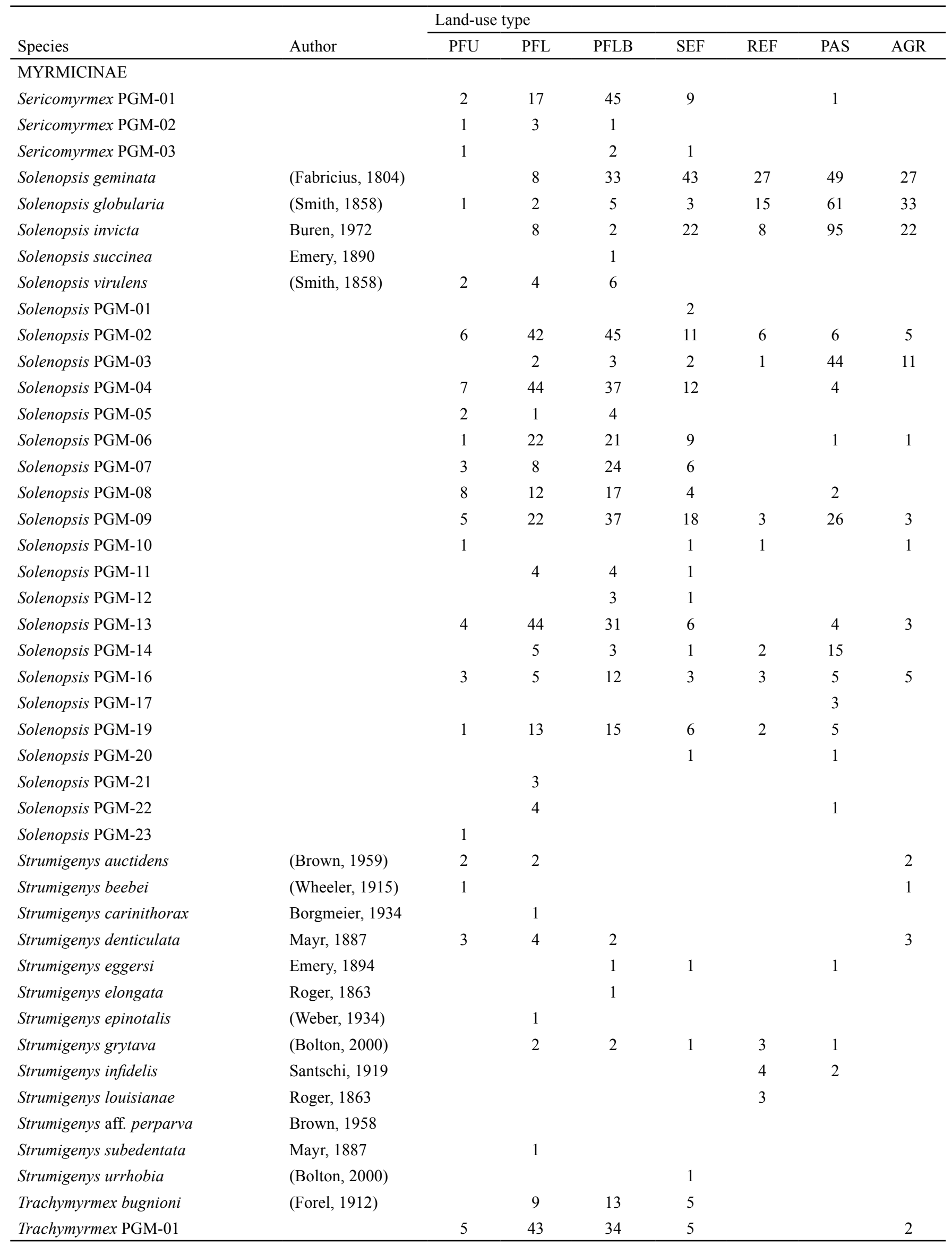


Table 2. List of ant species collected in this study. Values represent number of records per pitfall traps of each species in each land-use type: PFU - primary forest undisturbed, PFL - primary forest logged, PFLB - primary forest logged and burnt, SEF - secondary forest, REF reforestation with commercial species, PAS - pasture, AGR - agricultural areas. (Continuation)

\begin{tabular}{|c|c|c|c|c|c|c|c|c|}
\hline \multirow[b]{2}{*}{ Species } & \multirow[b]{2}{*}{ Author } & \multicolumn{7}{|c|}{ Land-use type } \\
\hline & & PFU & PFL & PFLB & SEF & REF & PAS & AGR \\
\hline \multicolumn{9}{|l|}{ MYRMICINAE } \\
\hline Trachymyrmex PGM-03 & & & 1 & 1 & & & & \\
\hline Wasmannia auropunctata & (Roger, 1863) & 12 & 52 & 9 & 36 & 11 & 81 & 8 \\
\hline \multicolumn{9}{|l|}{ PARAPONERINAE } \\
\hline Paraponera clavata & Smith, 1858 & & 2 & & & & & \\
\hline \multicolumn{9}{|l|}{ PONERINAE } \\
\hline Anochetus horridus & Kempf, 1964 & & 1 & & 1 & & & \\
\hline Anochetus diegensis & Forel, 1912 & & 1 & & & & & \\
\hline Hypoponera PGM-03 & & & & & & & 1 & \\
\hline Hypoponera PGM-04 & & & & 1 & & & & \\
\hline Leptogenys gaigei & Wheeler, 1923 & & 1 & 4 & & & & \\
\hline Mayaponera constricta & (Mayr, 1884) & 6 & 13 & 26 & 7 & 3 & 2 & \\
\hline Neoponera apicalis & (Latreille, 1802) & 12 & 68 & 51 & & & & \\
\hline Neoponera commutata & (Roger, 1860) & 2 & & & & & & \\
\hline Neoponera verenae & (Forel, 1922) & 4 & 5 & 56 & 7 & 1 & & 1 \\
\hline Odontomachus bauri & Emery, 1892 & & 7 & 21 & 2 & 7 & 11 & 2 \\
\hline Pachycondyla crassinoda & (Latreille, 1802) & 19 & 48 & 39 & 5 & & & 3 \\
\hline Pachycondyla harpax & (Fabricius, 1804) & 2 & 65 & 68 & 12 & 1 & & 1 \\
\hline Pachycondyla impressa & (Roger, 1861) & & & 5 & & & & \\
\hline Pachycondyla aff. purpurascens & Forel, 1899 & & & 1 & & & & \\
\hline Platythyrea sinuata & (Roger, 1860) & & & 1 & & & & \\
\hline Rasopone arhuaca & (Forel, 1901) & 1 & & & & & & \\
\hline \multicolumn{9}{|l|}{ PSEUDOMYRMECINAE } \\
\hline Pseudomyrmex termitarius & (Smith, 1855) & & 2 & 4 & 11 & 7 & 133 & 9 \\
\hline Pseudomyrmex gr. gracillis PGM-01 & & & & & 1 & & & \\
\hline Pseudomyrmex PGM-04 & & & & 1 & 1 & & & \\
\hline Pseudomyrmex gr. ocullatus PGM-03 & & & 1 & 6 & 2 & & & \\
\hline Pseudomyrmex gr. pallidus PGM-02 & & & & & & & 2 & \\
\hline
\end{tabular}

\footnotetext{
* new species
} 
Table 3. List of orchid bees species collected in this study. Values represent the number of individuals of each species in each land-use type: PFU - primary forest undisturbed, PFL - primary forest logged, PFLB - primary forest logged and burnt, SEF - secondary forest, REF reforestation with commercial species, PAS - pasture, AGR - agricultural areas.

\begin{tabular}{|c|c|c|c|c|c|c|c|c|}
\hline \multirow[b]{2}{*}{ Species } & \multirow[b]{2}{*}{ Author } & \multicolumn{7}{|c|}{ Land-use type } \\
\hline & & PFU & PFL & PFLB & SEF & REF & PAS & AGR \\
\hline Eufriesea auripes & (Gribodo, 1882) & & 2 & & & & 1 & \\
\hline Eufriesea ornata & (Mocsáry, 1896) & & & 6 & & & & \\
\hline Eufriesea pulchra & (Smith, 1854) & & & 1 & 4 & 1 & 3 & \\
\hline Eufriesea PGM-01 & & & & & 1 & & 2 & \\
\hline Eufriesea surinamensis & (Linnaeus, 1758) & & 2 & 1 & 5 & & 4 & \\
\hline Euglossa amazonica & Dressler, 1982 & 14 & 59 & 106 & 33 & 19 & 36 & 2 \\
\hline Euglossa augaspis & Dressler, 1982 & 7 & 24 & 15 & 8 & 3 & 8 & \\
\hline Euglossa bidentata & Dressler, 1982 & 1 & 3 & 3 & 2 & & 1 & \\
\hline Euglossa cordata & Friese, 1923 & 6 & 16 & 20 & 8 & 5 & 30 & 2 \\
\hline Euglossa chalybeata & Friese, 1925 & 6 & 16 & 23 & 6 & 1 & 2 & 1 \\
\hline Euglossa cognata & Moure, 1970 & & 4 & 4 & 10 & & & \\
\hline Euglossa crassipunctata & Moure, 1968 & 3 & 7 & & 3 & 1 & 1 & 1 \\
\hline Euglossa decorata & Smith, 1874 & & & & 1 & & & \\
\hline Euglossa despecta & Moure, 1968 & 1 & 6 & 30 & 24 & 1 & 17 & \\
\hline Euglossa ignita & Smith, 1874 & & 15 & 23 & 1 & & 1 & 1 \\
\hline Euglossa imperialis & Cockerell, 1922 & 16 & 77 & 102 & 16 & 6 & 8 & 6 \\
\hline Euglossa intersecta & Audouin, 1824 & 1 & 16 & 19 & 7 & 2 & 1 & \\
\hline Euglossa laevicincta & Dressler, 1982 & & 1 & & 1 & & & \\
\hline Euglossa liopoda & Dressler, 1982 & & 6 & 20 & 21 & 4 & 16 & 6 \\
\hline Euglossa aff. mixta & Friese, 1899 & 4 & 29 & 36 & 21 & 2 & 3 & \\
\hline Euglossa modestior & Dressler, 1982 & 6 & 12 & 17 & 12 & 6 & 40 & 6 \\
\hline Euglossa orellana & Roubik, 2004 & 5 & 30 & 12 & 8 & 1 & 1 & \\
\hline Euglossa parvula & Dressler, 1982 & & 2 & 17 & 1 & & & \\
\hline Euglossa PGM-01 & & & 1 & 3 & 4 & & 1 & \\
\hline Euglossa townsendi & Cockerell, 1904 & 26 & 84 & 113 & 109 & 3 & 7 & 3 \\
\hline Euglossa variabilis & Friese, 1899 & & 10 & & 2 & 1 & 5 & \\
\hline Eulaema bombiformis & (Packard, 1869 ) & 20 & 26 & 28 & 14 & 6 & 10 & 2 \\
\hline Eulaema cingulata & (Fabricius, 1804) & & 5 & 16 & 27 & 2 & 40 & 1 \\
\hline Eulaema marcii & Nemésio, 2009 & & 4 & 9 & 14 & 2 & 13 & 1 \\
\hline Eulaema meriana & (Olivier, 1789) & 19 & 83 & 65 & 38 & 6 & 44 & 21 \\
\hline Eulaema mocsaryi & (Friese, 1899) & & 3 & 8 & 10 & & & \\
\hline Eulaema nigrita & Lepeletier de Saint Fargeau, 1841 & & 24 & 16 & 29 & 35 & 1010 & 231 \\
\hline Eulaema pseudocingulata & Oliveira, 2006 & & & & & 1 & & \\
\hline Exaerete frontalis & (Guérin-Méneville, 1844) & 13 & 24 & 13 & 5 & 2 & 2 & \\
\hline Exaerete lepeletieri & Oliveira \& Nemésio, 2003 & & 1 & & 4 & & & \\
\hline Exaerete smaragdina & (Guérin-Méneville, 1844) & 1 & 11 & 15 & 2 & & 3 & \\
\hline
\end{tabular}




\section{References}

Abrahamczyk, S., de Vos, J.M., Sedivy, C., Gottleuber, P., and Kessler, M. (2014). A Humped Latitudinal Phylogenetic Diversity Pattern of Orchid Bees ( Hymenoptera: Apidae: Euglossini) in Western Amazonia: Assessing the Influence of Climate and Geologic History. Ecography, 37: 500-508. doi: 10.1111/j.1600-0587.2013.00417.x.

Abrahamczyk, S., Gottleuber, P., and Kessler, M. (2012). Seasonal Changes in Odour Preferences by Male Euglossine Bees (Hymenoptera: Apidae) and Their Ecological Implications. Apidologie, 43: 212-217. doi: 10.1007/s13592-011-0096-7.

Abrahamczyk, S., Gottleuber, P., Matauschek, C.\& Kessler, M. (2011). Diversity and Community Composition of Euglossine Bee Assemblages (Hymenoptera: Apidae) in Western Amazonia. Biodiversity and Conservation, 20: 2981-3001. doi: 10.1007/ s10531-011-0105-1.

Alvares, C.A., Stape, J.L., Sentelhas, P.C., de Moraes Goncalves, J.L.\& Sparovek, G. (2013). Koppen's Climate Classification Map for Brazil. Meteorologische Zeitschrift, 22: 711-728. doi: 10.1127/0941-2948/2013/0507.

Andrade, F.S. (2011). Variabilidade da Precipitação Pluviométrica de um Município do Estado do Pará. Engenharia Ambiental, 8: 138-145.

AntWeb. Available from http://www.Antweb.Org. Accessed 25th April 2016.

Baccaro, F.B., Feitosa, R.M., Fernández, F., Fernandes, I.O., Izzo, T.J., Souza, J.L.P.\&Solar, R.R.C. (2015). Guia Para Os Gêneros De Formigas Do Brasil. Editora INPA, Manaus, Brazil. doi: 10.5281/zenodo.32912.

Barlow, J., Ewers, R.M., Anderson, L., Aragao, L.E.O.C., Baker, T.R., Boyd, E., Feldpausch, T.R., Gloor, E., Hall, A., Malhi, Y., Milliken, W., Mulligan, M., Parry, L., Pennington, T., Peres, C.A., Phillips, O.L., Roman-Cuesta, R.M., Tobias, J.A.\& Gardner, T.A. (2011). Using Learning Networks to Understand Complex Systems: A Case Study of Biological, Geophysical and Social Research in the Amazon. Biological Reviews, 86: 457-474. doi: 10.1111/j.1469-185X.2010.00155.x.

Barlow, J., Lennox, G.D., Ferreira, J., Berenguer, E., Lees, A.C., Mac Nally, R., Thomson, J.R., Ferraz, S.F.D., Louzada, J., Oliveira, V.H.F., Parry, L., Solar, R.R.C., Vieira, I.C.G., Aragao, L., Begotti, R.A., Braga, R.F., Cardoso, T.M., de Oliveira, R.C., Souza, C.M., Moura, N.G., Nunes, S.S., Siqueira, J.V., Pardini, R., Silveira, J.M., Vaz-de-Mello, F.Z., Veiga, R.C.S., Venturieri, A., and Gardner, T.A. (2016). Anthropogenic Disturbance in Tropical Forests Can Double Biodiversity Loss from Deforestation. Nature, 535: 144-147. doi: 10.1038/ nature 18326.

Basset, Y., Cizek, L., Cuenoud, P., Didham, R.K., Guilhaumon, F., Missa, O., Novotny, V., Odegaard, F., Roslin, T., Schmidl,
J., Tishechkin, A.K., Winchester, N.N., Roubik, D.W., Aberlenc, H.-P., Bail, J., Barrios, H., Bridle, J.R., CastanoMeneses, G., Corbara, B., Curletti, G., da Rocha, W.D., de Bakker, D., Delabie, J.H.C., Dejean, A., Fagan, L.L., Floren, A., Kitching, R.L., Medianero, E., Miller, S.E., de Oliveira, E.G., Orivel, J., Pollet, M., Rapp, M., Ribeiro, S.P., Roisin, Y., Schmidt, J.B., Sorensen, L.\& Leponce, M. (2012). Arthropod Diversity in a Tropical Forest. Science, 338: 1481-1484. doi: 10.1126/science. 1226727.

Berenguer, E., Ferreira, J., Gardner, T.A., Aragão, L.E.O.C., De Camargo, P.B., Cerri, C.E., Durigan, M., Oliveira, R.C.D., Vieira, I.C.G.\& Barlow, J. (2014). A Large-Scale Field Assessment of Carbon Stocks in Human-Modified Tropical Forests. Global Change Biology, 20: 3713-3726. doi: 10.1111/ gcb. 12627.

Bolton, B.; http://antcat.org, accessed in April/2016. An Online Catalog of the Ants of the World. Available from http://antcat.org.

Christianini, A.V., Mayhe-Nunes, A.J.\& Oliveira, P.S. (2007). The Role of Ants in the Removal of Non-Myrmecochorous Diaspores and Seed Germination in a Neotropical Savanna. Journal of Tropical Ecology, 23: 343-351. doi: 10.1017/ s0266467407004087.

Colwell, R.K., Mao, C.X.\& Chang, J. (2004). Interpolating, Extrapolating, and Comparing Incidence-Based Species Accumulation Curves. Ecology, 85: 2717-2727. doi: 10.18 90/03-0557.

Fernández, F., editor. (2003). Introducción a Las Hormigas De La Región Neotropical. Instituto de Investigacíon de Recursos Biológicos Alexander von Humboldt, Bogotá, Colombia.

Folgarait, P.J. (1998). Ant Biodiversity and Its Relationship to Ecosystem Functioning: A Review. Biodiversity and Conservation, 7: 1221-1244. doi: 10.1023/a:1008891901953.

Gardner, T.A., Barlow, J., Araujo, I.S., Avila-Pires, T.C., Bonaldo, A.B., Costa, J.E., Esposito, M.C., Ferreira, L.V., Hawes, J., Hernandez, M.I.M., Hoogmoed, M.S., Leite, R.N., Lo-Man-Hung, N.F., Malcolm, J.R., Martins, M.B., Mestre, L.A.M., Miranda-Santos, R., Overal, W.L., Parry, L., Peters, S.L., Ribeiro-Junior, M.A., da Silva, M.N.F., Motta, C.d.S.\& Peres, C.A. (2008). The Cost-Effectiveness of Biodiversity Surveys in Tropical Forests. Ecology Letters, 11: 139-150. doi: 10.1111/j.1461-0248.2007.01133.x.

Gardner, T.A., Barlow, J., Chazdon, R., Ewers, R.M., Harvey, C.A., Peres, C.A.\& Sodhi, N.S. (2009). Prospects for Tropical Forest Biodiversity in a Human-Modified World. Ecology Letters, 12: 561-582. doi: 10.1111/j.1461-0248.2009.01294.x.

Gardner, T.A., Ferreira, J., Barlow, J., Lees, A.C., Parry, L., Guimaraes Vieira, I.C., Berenguer, E., Abramovay, R., Aleixo, A., Andretti, C., Aragao, L.E.O.C., Araujo, I., de Avila, W.S., Bardgett, R.D., Batistella, M., Begotti, R.A., Beldini, T., 
de Blas, D.E., Braga, R.F., Braga, D.d.L., de Brito, J.G., de Camargo, P.B., dos Santos, F.C., de Oliveira, V.C., Nunes Cordeiro, A.C., Cardoso, T.M., de Carvalho, D.R., Castelani, S.A., Mario Chaul, J.C., Cerri, C.E., Costa, F.d.A., Furtado da Costa, C.D., Coudel, E., Coutinho, A.C., Cunha, D., D’Antona, A., Dezincourt, J., Dias-Silva, K., Durigan, M., Dalla Mora Esquerdo, J.C., Feres, J., de Barros Ferraz, S.F., de Melo Ferreira, A.E., Fiorini, A.C., Flores da Silva, L.V., Frazao, F.S., Garrett, R., Gomes, A.d.S., Goncalves, K.d.S., Guerrero, J.B., Hamada, N., Hughes, R.M., Igliori, D.C., Jesus, E.d.C., Juen, L., Junior, M., de Oliveira Junior, J.M.B., de Oliveira Junior, R.C., Souza Junior, C., Kaufmann, P., Korasaki, V., Leal, C.G., Leitao, R., Lima, N., Lopes Almeida, M.d.F., Lourival, R., Louzada, J., Mac Nally, R., Marchand, S., Maues, M.M., Moreira, F.M.S., Morsello, C., Moura, N., Nessimian, J., Nunes, S., Fonseca Oliveira, V.H., Pardini, R., Pereira, H.C., Pompeu, P.S., Ribas, C.R., Rossetti, F., Schmidt, F.A., da Silva, R., Viana Martins da Silva, R.C., Morello Ramalho da Silva, T.F., Silveira, J., Siqueira, J.V., de Carvalho, T.S., Solar, R.R.C., Holanda Tancredi, N.S., Thomson, J.R., Torres, P.C., Vaz-de-Mello, F.Z., Stulpen Veiga, R.C., Venturieri, A., Viana, C., Weinhold, D., Zanetti, R.\&Zuanon, J. (2013). A Social and Ecological Assessment of Tropical Land Uses at Multiple Scales: The Sustainable Amazon Network. Philosophical Transactions of the Royal Society B-Biological Sciences, 368: doi: 10.1098/rstb.2012.0166.

Gascon, C., Lovejoy, T.E., Bierregaard, R.O., Malcolm, J.R., Stouffer, P.C., Vasconcelos, H.L., Laurance, W.F., Zimmerman, B., Tocher, M.\& Borges, S. (1999). Matrix Habitat and Species Richness in Tropical Forest Remnants. Biological Conservation, 91: 223-229. doi: 10.1016/s0006-3207(99)00080-4.

Hölldobler, B.\& Wilson, E.O. (2009). The Superorganism: The Beauty, Elegance, and Strangeness of Insect Societies. W. W. Norton \& Company, New York, NY, United States of America.

Janzen, D.H. (1971). Euglossine Bees as Long-Distance Pollinators of Tropical Plants. Science, 171: 203-\&. doi: 10.1126/science.171.3967.203.

Kalif, K.A.B., Azevedo-Ramos, C., Moutinho, P.\& Malcher, S.A.O. (2001). The Effect of Logging on the Ground-Foraging Ant Community in Eastern Amazonia. Studies on Neotropical Fauna and Environment, 36: 215-219. doi: 10.1076/snfe.36.3.215.2119.

Lach, L., Parr, C.\& Abbott, K. (2010). Ant Ecology. Oxford University Press, USA.

Laurance, W.F., Sayer, J.\& Cassman, K.G. (2014). Agricultural Expansion and Its Impacts on Tropical Nature. Trends in Ecology and Evolution, 29: 107-116 doi: 10.1016/j.tree.2013.12.001.

Lees, A.C., de Moura, N.G., Santana, A., Aleixo, A., Barlow, J., Berenguer, E., Ferreira, J.\& Gardner, T.A. (2012). Paragominas: A Quantitative Baseline Inventory of an Eastern Amazonian Avifauna. Revista Brasileira de Ornitologia, 20: 93-118.

Lindenmayer, D.B., Foster, D.R., Franklin, J.F., Hunter, M.L.,
Noss, R.F., Schmiegelow, F.A.\& Perry, D. (2004). Ecology Salvage Harvesting Policies after Natural Disturbance. Science, 303: 1303-1303. doi: 10.1126/science. 1093438.

Malhi, Y., Roberts, J.T., Betts, R.A., Killeen, T.J., Li, W.\& Nobre, C.A. (2008). Climate Change, Deforestation, and the Fate of the Amazon. Science, 319: 169-172. doi: 10.1126/ science. 1146961 .

Moura, N.G., Lees, A.C., Andretti, C.B., Davis, B.J.W., Solar, R.R.C., Aleixo, A., Barlow, J., Ferreira, J.\& Gardner, T.A. (2013). Avian Biodiversity in Multiple-Use Landscapes of the Brazilian Amazon. Biological Conservation, 167: 339348. doi: 10.1016/j.biocon.2013.08.023.

Nemesio, A. (2009). Orchid Bees (Hymenoptera: Apidae) of the Brazilian Atlantic Forest. Zootaxa, 1-242.

Nemesio, A. (2013). Are Orchid Bees at Risk? First Comparative Survey Suggests Declining Populations of Forest-Dependent Species. Brazilian Journal of Biology, 73: 367-374. doi: 10.1590/S1519-69842013000200017.

Nemesio, A. \& Rasmussen, C. (2011). Nomenclatural Issues in the Orchid Bees (Hymenoptera: Apidae: Euglossina) and an Updated Catalogue. Zootaxa, 1-42.

Nemesio, A. \& Silveira, F.A. (2007). Orchid Bee Fauna (Hymenoptera: Apidae: Euglossina) of Atlantic Forest Fragments inside an Urban Area in Southeastern Brazil. Neotropical Entomology, 36: 186-191. doi: 10.1590/s1519566x2007000200003.

Nemesio, A.\& Silveira, F.A. (2010). Forest Fragments with Larger Core Areas Better Sustain Diverse Orchid Bee Faunas (Hymenoptera:Apidae:Euglossina). Neotropical Entomology, 39: 555-561. doi: 10.1590/s1519-566x2010000400014.

Nemesio, A.\& Vasconcelos, H.L. (2013). Beta Diversity of Orchid Bees in a Tropical Biodiversity Hotspot. Biodiversity and Conservation, 22: 1647-1661. doi: 10.1007/s10531-013-0500-x.

Oksanen, J., Blanchet, F.G., Kindt, R., Legendre, P., Minchin, P.R., O’Hara, R.B., Simpson, G.L., Solymos, P., Stevens, M.H.H.\& Wagner, H. 2015. Vegan: Community Ecology Package. R Package Version, 2.3-0.

Oliveira, M.L.\& Campos, L.A.O. (1996). Preferências Por Estratos Forestais E Por Substâncias Odoríferas Em Abelhas Euglossinae (Hymenoptera, Apidae) Revista Brasileira de Zoologia, 13: 1075-1085.

Pimm, S.L.\& Raven, P. (2000). Biodiversity - Extinction by Numbers. Nature, 403: 843-845. doi: 10.1038/35002708.

Pinto, A., Amaral, P., Souza-Jr, C., Verissimo, A., Salomão, R., Gomes, G.\& Balieiro, C. 2009. Diagnóstico Socioeconomico E Florestal do Municipio de Paragominas. Imazon, Belém-PA.

PRODES-INPE. 2015. Projeto Prodes - Monitoramento da Floresta Amazônica Brasileira por satélite http://www.obt. inpe.br/prodes/index.php. 
R-Core-Team. 2015. R: A Language and Environment for Statistical Computing. R Foundation for Statistical Computing, Vienna, Austria. URL http://www.R-project.org/.

Rasmussen, C. (2009). Diversity and Abundance of Orchid Bees (Hymenoptera: Apidae, Euglossini) in a Tropical Rainforest Succession. Neotropical Entomology, 38: 66-73. doi: 10.1590/S1519-566X2009000100006

Santos, J.C., Delabie, J.H.C., and Fernandes, G.W. (2008). A 15-Year Post Evaluation of the Fire Effects on Ant Community in an Area of Amazonian Forest. Revista Brasileira de Entomologia, 52: 82-87. doi:10.1590/S008556262008000100015

Schmidt, F.A., Feitosa, R.M., Rezende, F.M.\& de Jesus, R.S. (2014). News on the Enigmatic Ant Genus anillidris (Hymenoptera: Formicidae: Dolichoderinae: Leptomyrmecini). Myrmecological News, 19: 25-30.

Schmidt, F.A.\& Solar, R.R.C. (2010). Hypogaeic Pitfall Traps: Methodological Advances and Remarks to Improve the Sampling of a Hidden Ant Fauna. Insectes Sociaux, 57: 261-266. doi: 10.1007/s00040-010-0078-1.

Solar, R.R.C., Barlow, J., Andersen, A.N., Schoereder, J.H., Berenguer, E., Ferreira, J.N. \& Gardner, T.A. (2016). Biodiversity Consequences of Land-Use Change and Forest Disturbance in the Amazon: A Multi-Scale Assessment Using Ant Communities. Biological Conservation, 197: 98-107. doi: 10.1016/j.biocon.2016.03.005.
Sousa-Souto, L., Schoereder, J.H.\& Schaefer, C.E.G.R. (2007). Leaf-Cutting Ants, Seasonal Burning and Nutrient Distribution in Cerrado Vegetation. Austral Ecology, 32: 758765. doi: 10.1111/j.1442-9993.2007.01756.x.

Storck-Tonon, D., Morato, E.F.\& Oliveira, M.L. (2009). Fauna de Euglossina (Hymenoptera: Apidae) da Amazônia Sul-Ocidental, Acre, Brasil. Acta Amazonica, 39: 693-706. doi: 10.1590/s0044-59672009000300026.

Underwood, E.C.\& Fisher, B.L. (2006). The Role of Ants in Conservation Monitoring: If, When, and How. Biological Conservation, 132: 166-182. doi: 10.1016/j.biocon.2006.03.022.

Viana, C., Coudel, E., Barlow, J., Ferreira, J., Gardner, T., and Parry, L. (2016). How Does Hybrid Governance Emerge? Role of the Elite in Building a Green Municipality in the Eastern Brazilian Amazon. Environmental Policy and Governance, 26: 337-350. doi: 10.1002/eet.1720.

Wilkie, K.T.R., Mertl, A.L.\& Traniello, J.F.A. (2007). Biodiversity Below Ground: Probing the Subterranean Ant Fauna of Amazonia. Naturwissenschaften, 94: 725-731. doi: 10.1007/s00114-007-0250-2.

Wilkie, K.T.R., Mertl, A.L., and Traniello, J.F.A. (2009). Diversity of Ground-Dwelling Ants (Hymenoptera: Formicidae) in Primary and Secondary Forests in Amazonian Ecuador. Myrmecological News, 12: 139-147 